\title{
Two new species of Collembola (Hexapoda) from Saliente Cave (Almería, Spain)
}

\author{
Rafael JORDANA \\ University of Navarra, Faculty of Sciences, Department of Environmental Biology, \\ University Campus, 31080 Pamplona (Spain) \\ rjordana@unav.es \\ (corresponding author) \\ Pablo BARRANCO \\ Department of Biology and Geology, Engineering High School, \\ University of Almería. Cite-IIB, 04120 Almería (Spain) \\ pablo.barranco@ual.es \\ Ana AMEZCUA \\ Enrique BAQUERO \\ University of Navarra, Faculty of Sciences, Department of Environmental Biology, \\ University Campus, 31080 Pamplona (Spain) \\ ebaquero@unav.es
}

Published on 31st March 2017

KEY WORDS

Arrhopalitidae, Arthropoda,

Pygmarrhopalites,

Pseudosinella,

Spain,

biospeleology, seasonal changes, new
urn:Isid:zoobank.org:pub:C2ABEE8B-F4BB-46D7-9BE9-4E5E425C9CB7

Jordana R., Barranco P., Amezcua A. \& Baquero E. 2017. - Two new species of Collembola (Hexapoda) from Saliente Cave (Almería, Spain). Zoosystema 39 (1): 103-115. https://doi.org/10.5252/z2017n1a12

\section{ABSTRACT}

Two new species of cavernicolous Collembola belonging to genera Pygmarrhopalites Vargovitsh, 2009 and Pseudosinella Schäffer, 1897 from "Cueva del Saliente" (Almería, Spain) are described: Pygmarrhopalites crepidinis Jordana \& Baquero, $n$. sp. is characterized by trichobothria A, B and C forming a straight line towards posterior end; Ant. IV with five subsegments; all claws with inner tooth, all empodia with corner tooth, and empodial filaments surpassing tip of corresponding claw; anterior lobe of tenaculum with two apical chaetae; dens with $3,2,1, \ldots, 1$ anterior chaetae, and one external posterior spine. Pseudosinella najtae Jordana \& Baquero, n. sp. is characterized by the absence of eyes; chaetotaxy R0R1R2011/10/0100+2, Abd. IV accessory chaeta s absent, all claws with four teeth, paired teeth at different level ( 41 and $52 \%$ of claw length from basis), all empodia with serrate external edge, labrum with all chaetae ciliated; labium posterior without M1, with M2rEL1L2, $\mathrm{r}$ smooth microchaetae; remaining of labial chaetae (both posterior and anterior) ciliated. In addition one other species was found in the same cave: Troglopedetes absoloni (Bonet, 1931). The explorations of this cave have been carried out by the second author. The "Cueva del Saliente" is part of a study on cave fauna in Andalusia. In this cave a total of 4453 specimens (38 taxa) have been captured during an annual sampling period (October 2012 to August 2013). 


\section{MOTS CLÉS \\ Arrhopalitidae, Arthropoda, Pygmarrhopalites, Pseudosinella Espagne, biospéléologie, changements saisonniers,
espèces nouvelles.}

\begin{abstract}
RÉSUMÉ
Deux nouvelles espèces de collemboles (Hexapoda) de la grotte de Saliente (Almería, Espagne).

Deux nouvelles espèces de collemboles cavernicoles appartenant aux genres Pygmarrhopalites Vargovitsh, 2009 et Pseudosinella Schäffer, 1897 et originaires de la "Cueva del Saliente» (Almería, Espagne) sont décrites: Pygmarrhopalites crepidinis Jordana \& Baquero, n. sp. est caractérisée par des trichobothries A, B et C formant une ligne droite vers la partie postérieure; Ant. IV avec cinq sous-segments; les griffes avec toutes une dent interne, tous les empodia avec une dent interne, et des filaments empodiaux dépassant la pointe de la griffe correspondante; le lobe antérieur du tenaculum avec deux soies apicales ; la dens avec 3,2,1, . 1 soies antérieures, et une épine postérieure externe. Pseudosinella najtae Jordana \& Baquero, n. sp. est caractérisée par l'absence d'yeux ; la chaetotaxie R0R1R2011/10/0100+2, Abd. IV sans soie s accessoire, toutes les griffes avec quatre dents, des dents paires décalées ( 41 et $52 \%$ de la longueur de la griffe en partant de la base), tous les empodia avec le bord externe dentelé, le labre avec toutes les soies ciliées; labium postérieur dépourvu de M1, avec M2rEL1L2, microsoies $r$ lisses; autres soies labiales (tant postérieures qu'antérieures) ciliées. En outre, une autre espèce a été trouvée dans la même grotte: Troglopedetes absoloni (Bonet, 1931). Les explorations de cette grotte ont été réalisées par le deuxième auteur. La "Cueva del Saliente» fait partie d'une étude sur la faune cavernicole en Andalousie. Dans cette grotte un total de 4453 spécimens (38 taxons) ont été capturés au cours d'un an d'échantillonnage (octobre 2012 à août 2013).
\end{abstract}

\section{INTRODUCTION}

Two cave projects have been developed along five years in order to protect invertebrate cave fauna in Andalusia (Belda et al. 2014). These projects were carried out in two periods: phase I (period 2009-2010) and phase II (20122013), during which 32 caves were sampled in the eight Andalusian provinces. Six caves were sampled in Almeria province during the whole period and Saliente cave was prospected during phase I. A wide variation has been observed in the arthropods abundance and ecological structure between caves. The highest number of captures took place in the province of Cadiz during phase I, and in Malaga during phase II.

A total of 187268 specimens of arthropods were processed and assigned to 104 taxonomic groups in a preliminary classification. The material was sent to specialized taxonomists and it is under study. These projects are expected to yield at least 33 new species, of wich 10 have been described already (Barranco 2010; Enghoff 2013; Molero et al. 2013; Ortuño \& Barranco 2015; Ribera \& De Más 2015). The material obtained as part of these projects also has allowed the redescription of rare forms and provided new data on known species (Ortuño \& Barranco 2013; Gómez et al. 2013; Barranco et al., 2014; Tinaut et al. 2015).

The relevance of the taxonomic and faunistic results obtained in the present study, has driven to the execution of some preservation measures for the protection of the fauna. These measures include, depending on each case, the installation of fences around the entrance of the caves, to close the entrance cleaning of the caves and signaling of the entomology importance of the cavern using informative boards (Belda et al. 2014).

In this paper, together with further information on the fauna found in the "Cueva del Saliente", two new species of Collembola are described.

\section{MATERIAL AND METHODS}

\section{CAVE DESCRIPTION}

The Saliente Cave is located in the mountains of the same name, on the hill of the Ermita, municipality of Oria, in Almeria province (Spain). The entrance is located at $1170 \mathrm{~m}$ a.s.l. UTM coordinates in 30S, X573269, Y4153731. The cavity is developed on alpujarrides carbonates in favor of a large area of fracture of NNW-SSE direction. In this area successive fractures have slipped a large carbonated block that has broken off the alignment which forms the sierra (González 2015). It is a cavity where gravitational structures are dominant, with abundant chaos of blocks, diaclases, fractures and collapses. There are superimposed galleries up to four levels. Its complex structure, with spacious halls and labyrinthine galleries developed among large detached blocks, makes the topographical survey very complicated, which reaches $1190 \mathrm{~m}$ of accessible galleries, with maximum slope of $-56 \mathrm{~m}$ (Fig. 1). In the cavity there is a large colony of bats, as well as an archaeological site.

\section{MeTHODS}

The fauna was collected over two sampling periods. A first preliminary sampling was conducted to determine the faunal potential capacity of the cavity (date setting of traps/collection date, 20.XI.-18.XII.2011). The following year we began a one-year study, placing traps at the stations established during the preliminary sampling (28.X-01.XII.2012, 17.II-. III.2013; 17.III-21.IV.2013; 26.VI.-10.VIII.2013). In these dates, 11 pitfall traps were installed throughout the cavity (Fig. 1). Each trap consists of vials $120 \mathrm{ml}$ and a diameter of $5.2 \mathrm{~cm}$ mouth buried at the substrate level and filled up to half its capacity with a solution composed of $2 / 3$ propylene glycol and $1 / 3$ beer solution, and primed with spicy sausage. The traps remained active for about a month. The material extracted from each trap and that captured by hand was stored in $70 \%$ ethyl alcohol. 


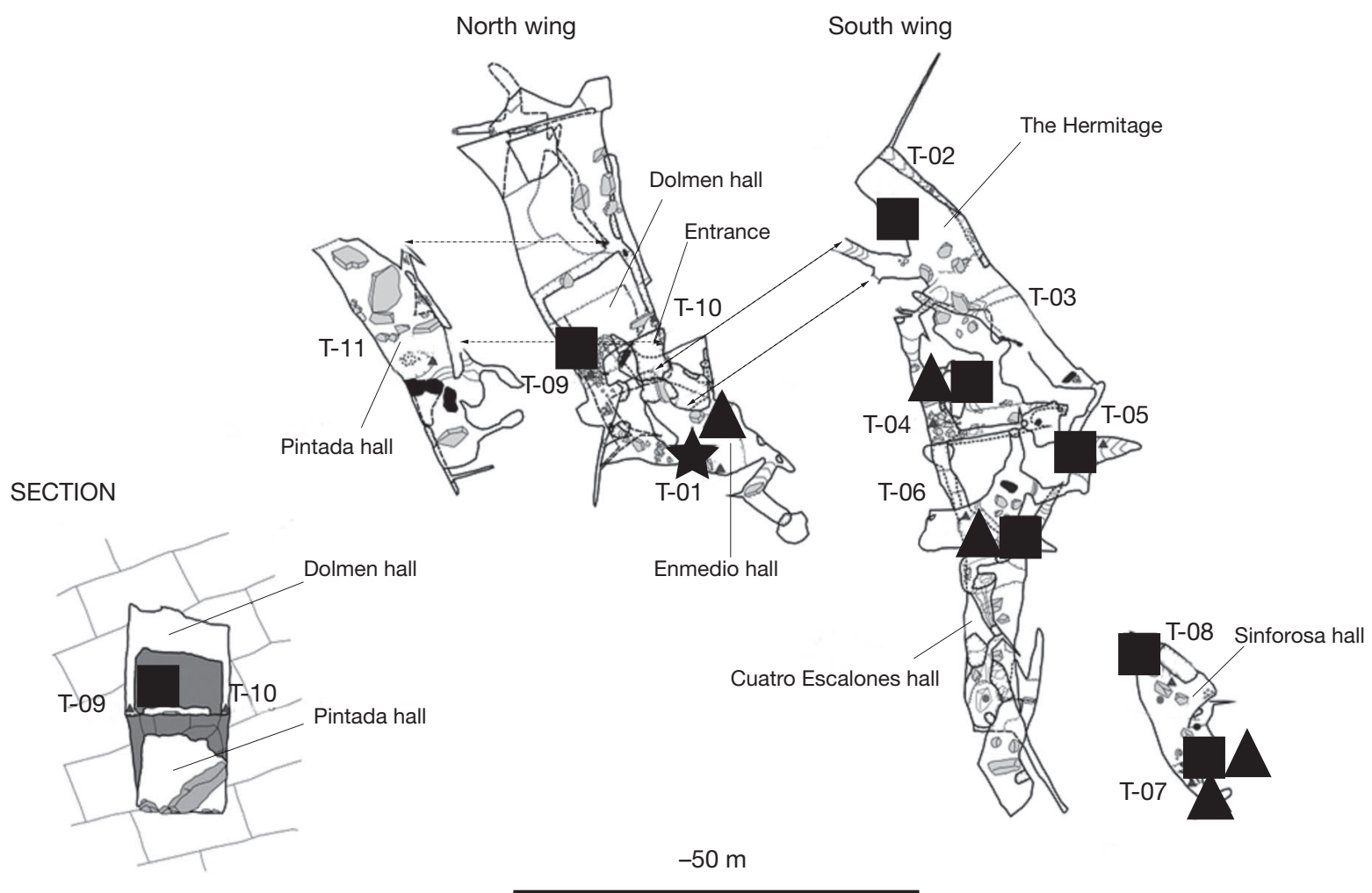

PROFILES
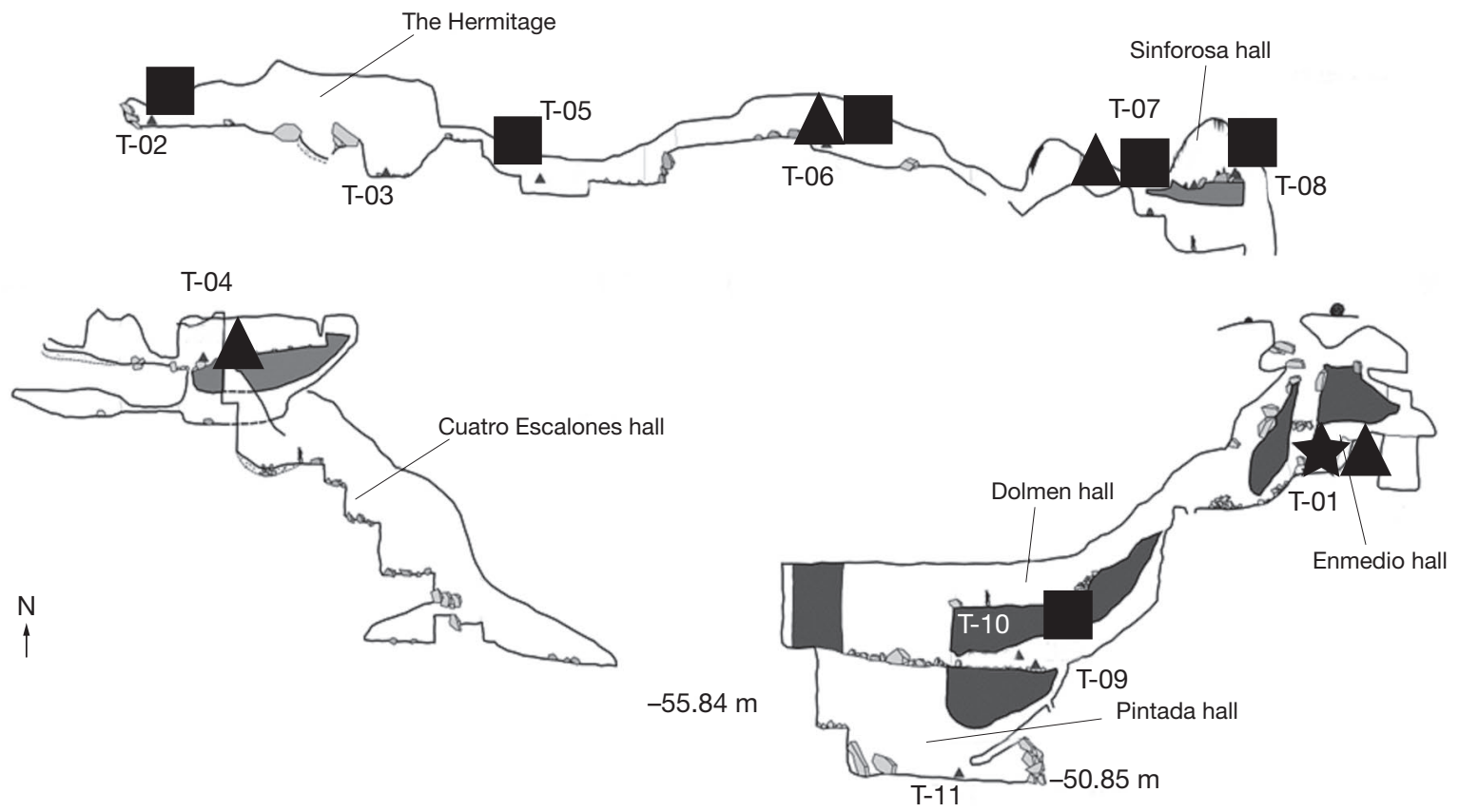

FIG. 1. - Topography of Cueva del Saliente and distribution of species of Collembola. Symbols: Star, Troglopedetes absoloni Bonet, 1931; triangle, Pseudosinella najtae Jordana \& Baquero, n. sp.; square, Pygmarrhopalites crepidinis Jordana \& Baquero, n. sp. T-1 to T-11 pitfall locations. Map base from the Asociación Espeleológica Velezana. 
Relative humidity $(\mathrm{RH})$ and temperature $(\mathrm{T})$ were recorded at hourly intervals during the sampling period by an Electronic Dostmann LOG32 USB Data Logger located in the Sinforosa Hall (traps 7 and 8, topography see Fig. 1). During this period the $\mathrm{RH}$ was $100 \%$ (ranging from $99.7-100 \%$ ) and the average $\mathrm{T}$ of $13.6^{\circ} \mathrm{C}$ (ranging from 13.5 to $13.7^{\circ} \mathrm{C}$ ).

Some specimens were cleared in Nesbitt's fluid and, after washing for one hour in 70\% Ethyl alcohol, were mounted in Hoyer's medium for compound microscope observation in phase contrast and differential interface contrast (DIC). Some specimens were studied with a scanning electron microscope (SEM). Specimens from 70\% ethyl alcohol were slowly rehydrated in decreasing series of its concentration $(60 \%, 50 \%, 40 \%, 30 \%, 20 \%, 10 \%$, distilled water) along 24 hours. Once in distilled water they were fixed in $4 \%$ glutaraldehyde in cacodylate buffer for $24 \mathrm{~h}$, and then transferred to sucrose $0.25 \mathrm{M}$ for $24 \mathrm{~h}$. The specimens were then dehydrated up to $100 \%$ ethyl alcohol. Complete dessiccation was achieved by the $\mathrm{CO}_{2}$ critical point technique. Samples were then covered with a $16 \mathrm{~nm}$ thin layer of molecular gold using an Emitech K550 sputter coater. Observations were done with a Zeiss Digital Scanning Microscope 940 A. The chaetotaxy for Pygmarrhopalites Vargovitsh, 2009 follows Fjellberg (1998) for the labial palp, Fjellberg (1984) for the outer maxillary palp, Christiansen \& Bellinger (1996) for antennal III sensory organ, Bretfeld (1999) for Abd. VI, Christiansen (1966) and Christiansen \& Bellinger (1980) for empodium, and Vargovitsh (2009), for head, body and legs. The chaetotaxy for Pseudosinella follows Gisin \& Da Gama 1969, Szeptycki (1979) and Soto-Adames (2010). The characters defined by Christiansen et al. (1990) for Pseudosinella and the characters used by Christiansen in Jordana et al. (2016) in theirs Delta key have been used for identification and description.

\section{ABREVIATIONS}

Abd. abdomen or abdominal segment I-VI;

Ant antennal or antenna/ae;

CIA Cave Invertebrate Andalusia;

DIC Differential Interference Contrast;

Mc Macrochaeta/ae;

RH Relative humidity;

SEM Scanning Electron Microscope;

T temperature;

Th Thorax or thoracic segments II-III.

\section{Institutions}

CECOUAL Centro de Colecciones de la Universidad de Almería; MNHG Musée d'Histoire naturelle, Genève;

MNCN Museo Nacional de Ciencias Naturales, Madrid;

MNHN Muséum national d'Histoire naturelle, Paris;

MZ Museum of Zoology, University of Navarra (Pamplona).

\section{RESULTS}

The only Collembola found in this cave are the two new species and Troglopedetes absoloni Bonet, 1931, common in caves of Andalusia, Spain (Soto-Adames et al. 2014).

\section{SYSTEMATICS}

Class COLLEMBOLA Lubbock, 1870

Order SYMPHYPLEONA Börner, 1901

Family ARRHOPALITIDAE Stach, 1956

Genus Pygmarrhopalites Vargovitsh, 2009

Pygmarrhopalites crepidinis Jordana \& Baquero, n. sp. (Figs 2A-C; 3A-G, 4A-K; Table 1)

TyPe MATERial. - Holotype. 9 in slide, date 21.IV.2013. Cueva del Saliente, Sierra de las Estancias, Cerro de la Ermita, Término Municipal de Oria (Almería, Spain), pitfall 08, slide CIA-MZ20130421a, Barranco-ECA leg.

Paratypes. Barranco-ECA leg.: CIA-MZ-20130421d, 1 \% on slide, 21.IV.2013, pitfall 08; MZ-20130421e, 1 9 on slide, 21.IV.2013, pitfall 08; MZ-20130421f, 1 o on slide, 21.IV.2013, pitfall 08; MZ20130421g, 1 \% on slide, 21.IV.2013, pitfall 08; MZ-20130421 h, 1 o" (juvenile) on slide, 21.IV.2013, pitfall 07; MZ-20130421i, 1 specimen on slide, 21.IV.2013, pitfall 09; MZ-20130421j, 1 specimen juvenile on slide, 21.IV.2013, pitfall 02; CIA-MZ-20130421k and 1, 2 o on SEM stub, 21.IV.2013, pitfall 08; MZ-20130810a, 1 ㅇ on slide, 10.VIII.2013, pitfall 05; MZ-20130810b, 1 \% on slide, 10.VIII.2013, pitfall 05; MZ-20130317a, 1 o on slide, 17.III.2013, pitfall 09; (deposited in MZ). CIA-MNHN-20130421b, 1 우 in slide, 21.IV.2013, pitfall 08, 3 in ethyl alcohol 70\% (MNHN); CIA-MNCN-20130421c, 1 \% on slide, 21.IV.2013, pitfall 08, 3 in ethyl alcohol 70\% (MNCN); CIA-CECOUAL-20130317b, 2 o on the same slide, 17.IIV.2013, pitfall 08; CIA-CECOUAL-20130321, 3 in ethyl alcohol 70\% (CECOUAL).

COMPlementary MATERIAl. - Cueva del Saliente (BarrancoECA/AEV leg): CIA-MZ-20111218a, 1 specimen juvenile in slide, 18.XII.2011, pitfall 08; CIA-MZ-20111218b, 1 specimen juvenile in slide, 18.XII.2011, pitfall 02; CIA-MZ-20111218c, 1 ㅇ on slide, 18.XII.2011, pitfall 07; CIA-MZ-20111218d, 1 ㅇ on slide, 18.XII.2011, pitfall 09; CIA-MZ-20111218e, 1 specimen juvenile on slide, 18.XII.2011, pitfall 08b; CIA-MZ-20111218f, 1 o on slide, 18.XII.2011, pitfall 04; CIA-MZ-20111218g, 1 응 slide, 18.XII.2011, pitfall 07. Cueva del Saliente (Barranco-ECA leg): CIA-MZ-20121201a, 1 specimen juvenile on slide, pitfall 07; CIA-MZ-20121201b, 19 on slide, 1.XII.2012, pitfall 06; CIAMZ-20121201c, 1 \% on slide, 1.XII.2012, pitfall 05.

ETYMOLOGY. - The new species is named after Latin name of the cave: crepido, crepidinis.

DiagNosis. - Unpigmented; $1+1$ eyes; trichobothria A, B and $\mathrm{C}$ forming a straight line towards hind part; Ant. IV subdivided into five subsegments; all claws with inner tooth, all empodia with corner tooth, and empodial filaments overtopping tip of corresponding claw; anterior lobe of tenaculum with two apical chaetae; dens with 3,2,1..1 anterior chaetae, posterior side with one external spine; mucro gutter-like, both edges serrated, tip rounded; some circumanal chaetae broadened with wings but in some specimens with a basal spine in a3 without subbasal serration; anal appendices gutter-like, with apical and lateral end serration.

\section{DESCRIPTION}

General

Body length $1.05 \mathrm{~mm}(\mathrm{n}=16)$ (holotype $1.22 \mathrm{~mm})$, pigmentation absent. Habitus as Figure 2A. 


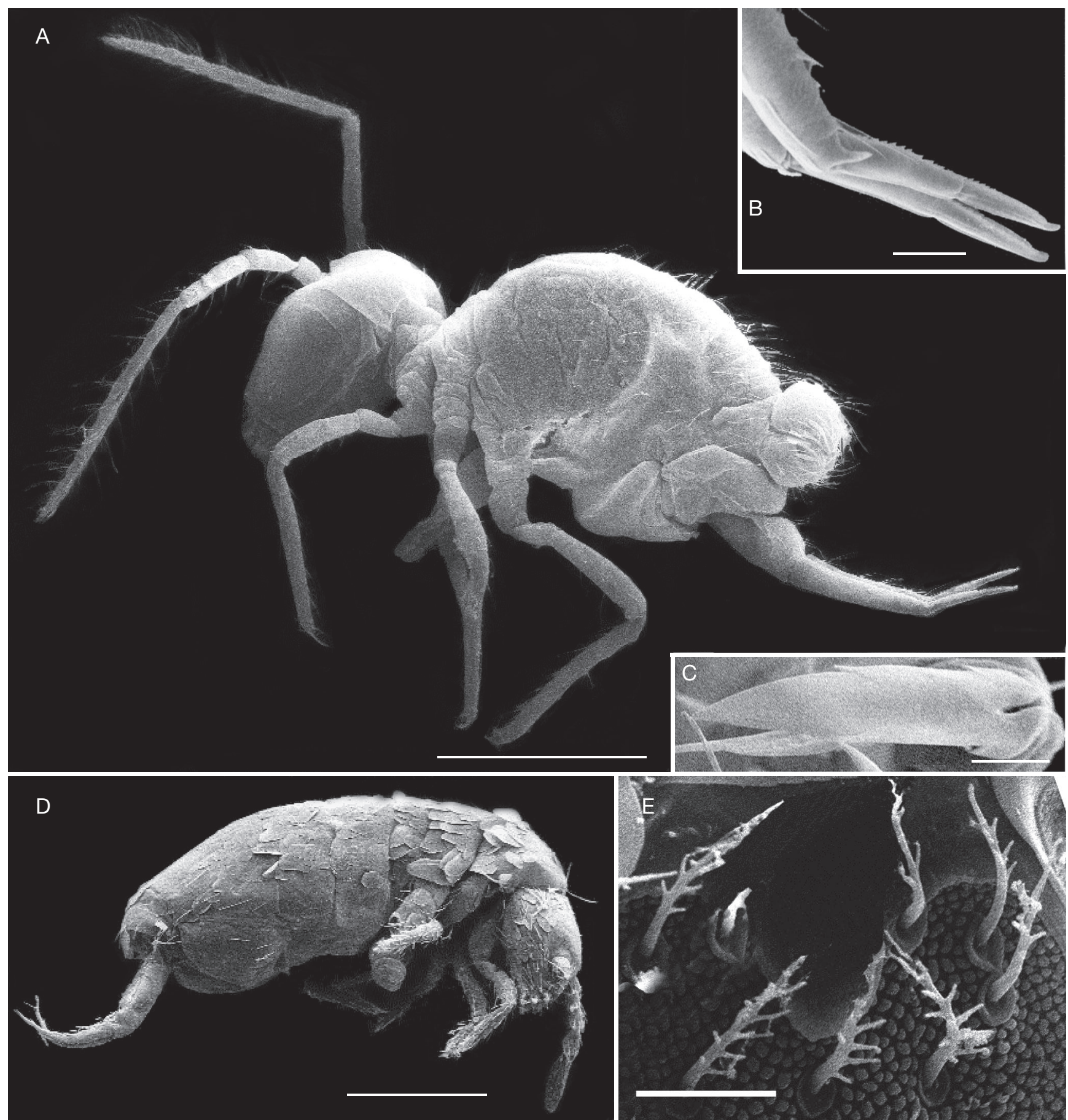

FIG. 2. - A-C, Pygmarrhopalites crepidinis Jordana \& Baquero, n. sp.: A, habitus; B, end of dens and mucro; C, dorsal view of claw of leg 3; D, E, Pseudosinella najtae Jordana \& Baquero, n. sp.: D, habitus, E, Labrum detail. Scale bars: A, $300 \mu \mathrm{m} ; \mathrm{B}, 30 \mu \mathrm{m} ; \mathrm{C}, 9 \mu \mathrm{m} ; \mathrm{D}, 200 \mu \mathrm{m}, \mathrm{E}, 4 \mu \mathrm{m}$.

\section{Female}

Head (Fig. 3A, C). Length $0.34 \mathrm{~mm}(\mathrm{n}=18)$. Eyes $1+1$. No spine-like chaetae on the head.Clypeal area: 6 rows (from $a$ to $f$ ); row $a$ with axial chaeta, one axial chaeta between $c, d$ and $e$ rows. Inter-antennal area with 2 rows ( $a$ and $\beta$ ) without axial chaetae. Dorsal area: 4 rows (from A to D) with 4 axial chaetae in rows A, B, C and D; B without lateral chaetae (Vargovitsh 2009). Labral chaetae number a: 4, m: 5, p: 5; prelabral: 6 (Fig. 3C). Labial palp with papillae A-E as in Figure 3E (Fjellberg 1998); maxillary outer lobe with three sublobal chaetae, and palp with basal spine (Fig. 3D) (Fjellberg 1984).

Antennae (Fig. 4A-D). 2 times as long as head $(\mathrm{n}=16)$. Ant. length $0.70 \mathrm{~mm}(\mathrm{n}=16)$, ratio of Ant segments I : II : III $:$ IV $=1: 1.9: 3.0: 7.9$ (average for $\mathrm{n}=17$ ). Ant. I with 7 chaetae, subapical posterior chaeta minute; Ant. II with 15 simple chaetae (Fig. 4A). Ant. III not swollen on sub-basal 

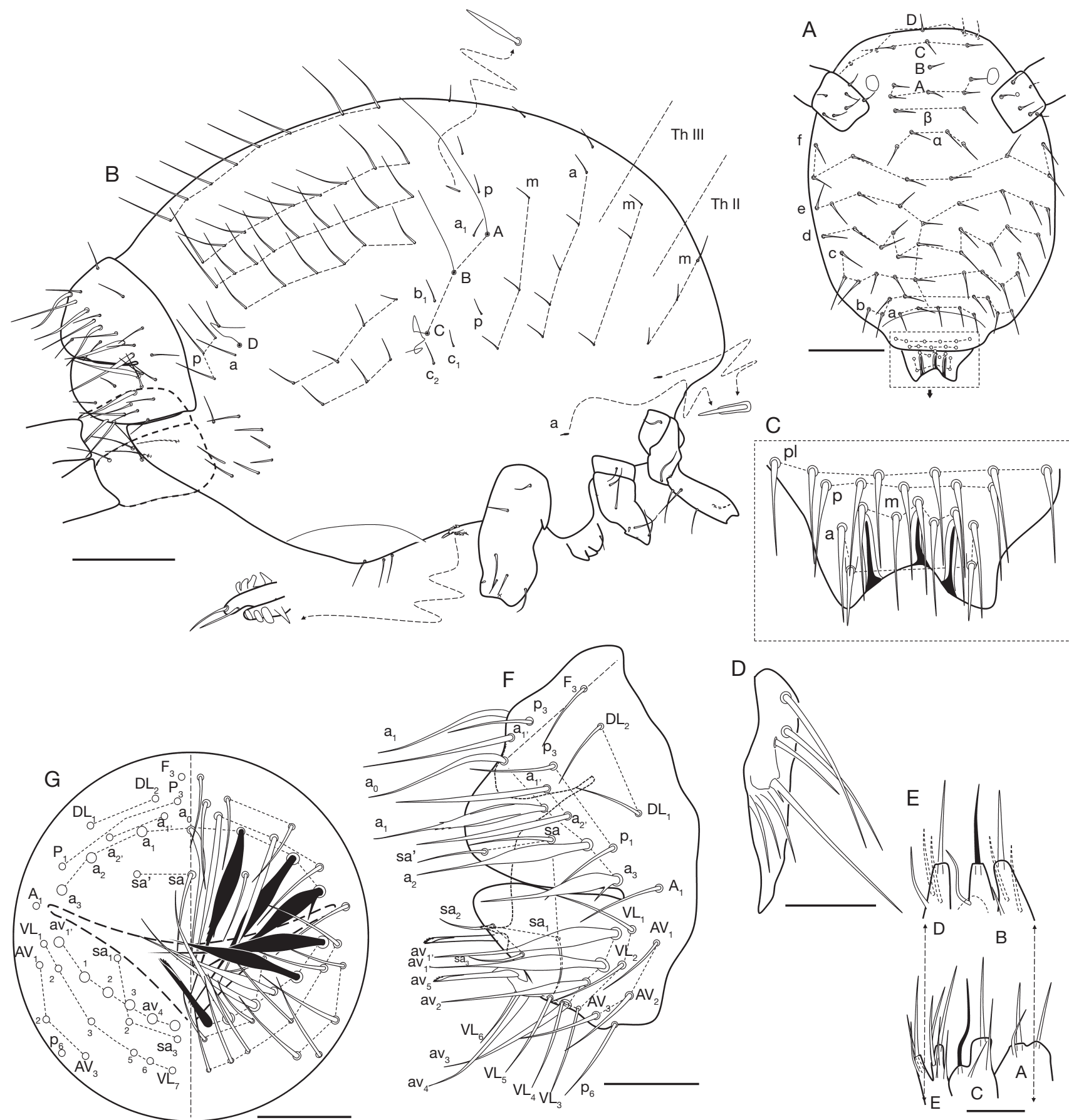

FIG. 3. - Pygmarrhopalites crepidinis Jordana \& Baquero, n. sp.: A, head chaetotaxy, nomenclature for head chaetae rows: A-C and $\mathbf{D}$, vertex; $\boldsymbol{a}$ and $\boldsymbol{\beta}$, interantennal, a, b, c, d, e and f, clypeal area; pl, prelabral row; B, body chaetotaxy; C, labrum chaetotaxy (pl, prelabral row; p, posterior; m, medial; a, anterior); D, maxillary outer lobe; E, labial papillae A to E (posterior papillae drawn separately); F, Abd. VI chaetotaxy; G, schematic posterior view of Abd. VI. Scale bars: A, F, G, $50 \mu \mathrm{m} ; \mathrm{B}, 100 \mu \mathrm{m} ; \mathrm{C}, \mathrm{D}, 20 \mu \mathrm{m} ; \mathrm{E}, 10 \mu \mathrm{m}$.

or medial part, with 17 chaetae and 2-rods sense organ; microsensillum Aai, chaetae Api and Ap straight, chaetae Ape, Ae and Ai curved (Fig. 4B). Ant. IV with 5 subsegments; subsegmental formula: $1+3+1$. AntIV bears the following whorls of chaetae: 5 on basal subsegment (BA, BM1-BM3, $\mathrm{BB}), 3$ on medial subsegments each, and 5 on apical subsegment: AI-AIII, M1-M2 (after Vargovitsh, 2009) (Fig. 4C,
D).Two species organites present and very patent on Ant. IV: subapical one with sphaeroidal big tip and apically special curved guard sensillum (Fig. 4D)

Legs (Fig. 4E-J). Foreleg: precoxae 1, 2 and coxa with 1, 0, 1 chaetae respectively; trochanter with 3 anterior and 1 posterior chaetae; femur with 13 chaetae, a 4 bending perpendicularly 


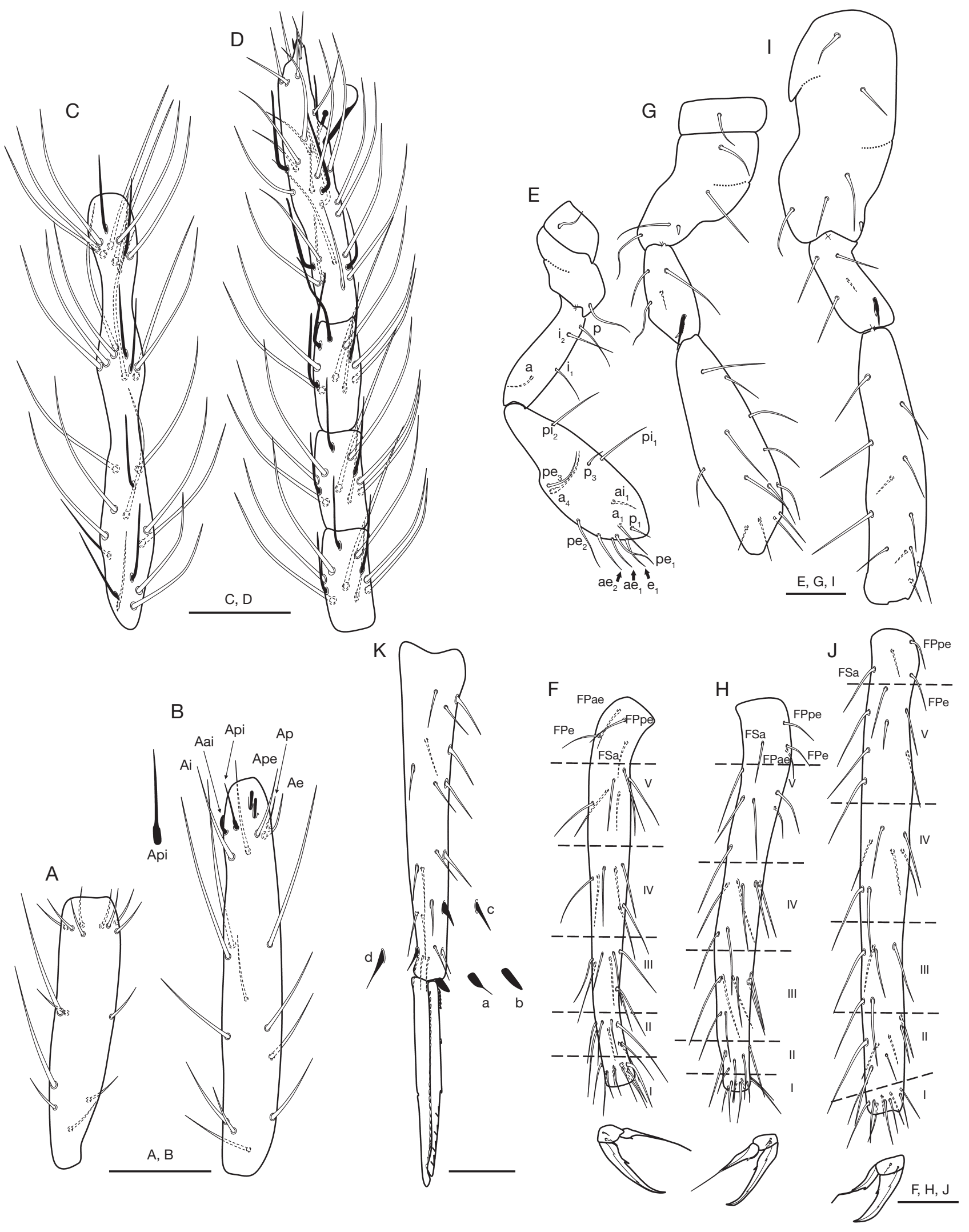

FIG. 4. - Pygmarrhopalites crepidinis Jordana \& Baquero, n. sp. A, Ant. II; B, Ant. III; C, Ant. IV basal subsegment; D, Ant. IV distal four subsegments; E, subcoxae, coxa, trochanter and femur of leg 1, posterior view; $\mathbf{F}$, tibiotarsus and claw of leg 1, posterior view; G, subcoxae, coxa, trochanter and femur of leg 2, anterior view; $\mathbf{H}$, tibiotarsus and claw of leg 2, anterior view; I, subcoxae, coxa, trochanter and femur of leg 3, anterior view; J, tibiotarsus and claw of leg 3 , anterior view; K, dens and mucro; a, b, c and d spines variations. Scale bars: $50 \mu \mathrm{m}$ 
to the longitudinal axis of the segment (Fig. 4E) and pe3 in a similar position; tibiotarsus (Fig. $4 \mathrm{~F}$ ) with 3 chaetae FP (FPe, FPae, FPpe) and chaeta FSa present; whorl I with 9 chaetae; whorls II-V with 8 chaetae each. Pretarsus with 1 anterior and 1 posterior chaetae. Claw with inner tooth and 2 pairs of lateral teeth visible in ventral view (Fig. 4F), tunica absent. Empodium thin, with corner tooth in subbasal half, with long apical filament exceeding tip of claw. Claw 4.5 times shorter than tibiotarsus. Mid leg: precoxae 1, 2 and coxa with 1, 1, 3 chaetae respectively; coxa with an additional spine; trochanter with 3 anterior simple chaetae, 1 posterior chaeta and anterior trochanteral organ; femur with 13 chaetae, 2 posterior ones smaller (Fig. 4G); tibiotarsus with 3 chaetae FP present, chaeta FSa present; whorl I with 9 chaetae, whorls II-III with 8 chaetae, whorl IV-V with 7 chaetae in different arrangement; claw broader than in foreleg, with inner tooth and 2 pairs of lateral teeth (Fig. 4H), tunica absent; empodium broader than in foreleg, with corner tooth in subbasal part; apical filament exceeding tip of claw; claw 5.5 times shorter than tibiotarsus (Fig. 4H). Hind leg: precoxae with 1, 1 chaetae and coxa with 3 chaetae and 1 small spine; trochanter with anterior trochanteral organ, 3 anterior and 1 posterior simple chaetae; femur with 10 anterior and 2 posterior chaetae (Fig. 4I); tibiotarsus with 3 chaetae FP, chaeta FSa present; whorls I-V as in mid tibiotarsus; claw broader than in fore and mid leg, with inner tooth and 2 pairs of lateral teeth (Fig. 4J); empodium broader than in the other legs, with corner tooth in the middle, and apical filament exceeding tip of claw; claw 7.5 times shorter than tibiotarsus (Fig. 4J). Length ratio of tibiotarsi I $:$ II $:$ III $=1: 1.1: 1.3$.

Great abdomen (Fig. 3A). Meso- and metathorax with normal dorsal chaetae, 1 neosminthuroid chaeta a on Th II and III. Trichobothria A, B and C forming a straight line towards hind part. Single p chaeta of p-row of Abd. I is located below the level of $B$ trichobothrium, chaeta a 1 placed posterior to A trichobothrium, b1 placed between $\mathrm{B}$ and $\mathrm{C}$ trichobotria, chaeta $\mathrm{c} 1$ and $\mathrm{c} 2$ below $\mathrm{C}$ trichobothrium. Posterior lateral complex with $4+3$ and furca base complex with 8 chaetae. Posterior dorsal complex with about 23 chaetae arranged in 3 rows. Ventral complex with 3 chaetae. Tenaculum with 3 teeth, a basal peg-like projection and 2 chaetae.

Furca. Manubrium with $5+5$ posterior chaetae. Dens (Fig. 4K) with $3,2,1, . ., 1$ anterior chaetae, 3 inner, 6 dorsal and 7 external chaetae; two external spines with variable morphology as Figure $4 \mathrm{~K}(\mathrm{a}, \mathrm{b}, \mathrm{c})$ and 1 internal spine like chaeta $(\mathrm{d})$.

Great abdomen. Abd. V with 2 chaetae and trichobothrium D in row a, and 3 chaetae in row p (Fig. 3B). Abd. VI (Fig. 3F, $\mathrm{G})$ without cuticular spines; some circumanal chaetae broadened with wings usually smooth, sometimes with weak distal serrations or basal spur (a1 and a3); chaeta A1 shorter than chaeta $\mathrm{a} 0$ and DL2; subanal appendages (av5) gutter like, with apical serration.
Order ENTOMOBRYOMORPHA Börner, 1913, sensu Soto-Adames et al. (2008)

Family ENTOMOBRYIDAE Tömösvary, 1882 Subfamily ENTOMOBRYINAE Schäffer, 1896

Tribe LEPIDOCYRTINI Yoshii \& Suhardjono, 1989 Genus Pseudosinella Schäffer, 1897

\section{Pseudosinella najtae Jordana \& Baquero, n. sp.} (Figs 2D, E; 5A-K)

Type MATERIAL. - Holotype. + , slide CIA-MZ-20130421a, Cueva del Saliente, Sierra de las Estancias, Municipality of Oria, Almería, 21.IV.2013, pitfall 07, Barranco Leg. (as the remaining specimens of type series).

Paratypes. CIA-MZ-20130421f to k, six specimens in ethyl alcohol, 21.IV.2013, pitfall 07; CIA-MZ-201304211 to u, 10 specimens in ethyl alcohol, 21.IV.2013, pitfall 06; CIA-MZ-20130421l to m, two specimens mounted in SEM stub, 21.IV.2013, pitfall 07; CIA-MZ20130421b, $P$ in slide, 21.IV.2013, pitfall 06; CIA-MZ-20130421c, juvenile in slide, 21.IV.2013, pitfall 06; CIA-MZ-20130810a, $\mathrm{b}$ and $\mathrm{c}, \mathrm{o}^{*}$, $\%$ and juvenile in the same slide, 10.VIII.2013, pitfall 06; CIA-MZ-20130810d, o in slide, 10.VIII.2013, pitfall 06; CIA-MZ-20130317b, juvenile in slide, 17.III.2013, pitfall 01; CIA-MZ-20130317c, juvenile in slide, 17.III.2013, pitfall 06 (MZ). CIA-MNHN-20130421d, $\%$ in slide, 21.IV.2013, pitfall 06 (MNHN). CIA-CECOUAL-20130421e, $\%$ in slide, 21.IV.2013, pitfall 06 (CECOUAL). CIA-MNCN-20130317a, $\odot$ in slide, 17.VIII.2013, pitfall 04 (MNCN).

Etymology. - The species name is dedicated to Judith Najt.

Diagnosis. - Unpigmented; without eyes; chaetotaxy R0R1R2011/10/0100+2, without s accessory chaetae on Abd. IV, all claws with four teeth, paired teeth at different level (50\% of claw length), all empodia with serrate external edge, labrum with all chaetae ciliated. Labium without M1, with M2rEL1L2, $r$ is a smooth microchaetae, all labial chaetae both basal and internal ciliated.

\section{DESCRIPTION}

General

Maximum length $817 \mu \mathrm{m}$, mean length $727 \mu \mathrm{m}(\mathrm{n}=8)$, (holotype $780 \mu \mathrm{m}$ ) (Fig. 2D). Without pigment.

\section{Head}

Without eyes. Ratio antenna/cephalic diagonal 1.28, antennal segments I/II/III/IV ratios 1/1.5/1.4/2.8 (average $\mathrm{n}=7$ ). Sensorial chaetae $s$ on antennal segment III short, slightly curved and rod like (Fig. 5D) similar sensillae are present in external and lateral part of Ant. II and IV. Apical vesicle present on Ant. IV. Labrum chaetotaxy as in Figure 5A, all chaetae ciliated (SEM microphotograph in Figure 2E). Formula of the labial base (Fig. 5B): MrEL1L2, all chaetae ciliated, $r$ as smooth microchaetae. Antennae without scales.

\section{Body chaetotaxy}

Formula of the dorsal macrochaetae: R011/10/0100+2. R Mc complex with R0, R1 and R2. S (M) as microchaeta, T and S present as Mc (Fig. 5C). Abd. II chaetotaxy: -aBq1q2 (Fig. 5J), without $\mathrm{p}(\mathrm{a} 2 \mathrm{p})$ chaeta, $\mathrm{a} 2 \mathrm{i}$ as ciliated microchaeta, a2 as smooth microchaeta. B (m3) ciliated and long macrochaeta, as in normal location, a3 near and external to as. q1 (a3e) and q2 (p4) as smooth microchaetae. Abd. III with a2i, a6-a6ii 

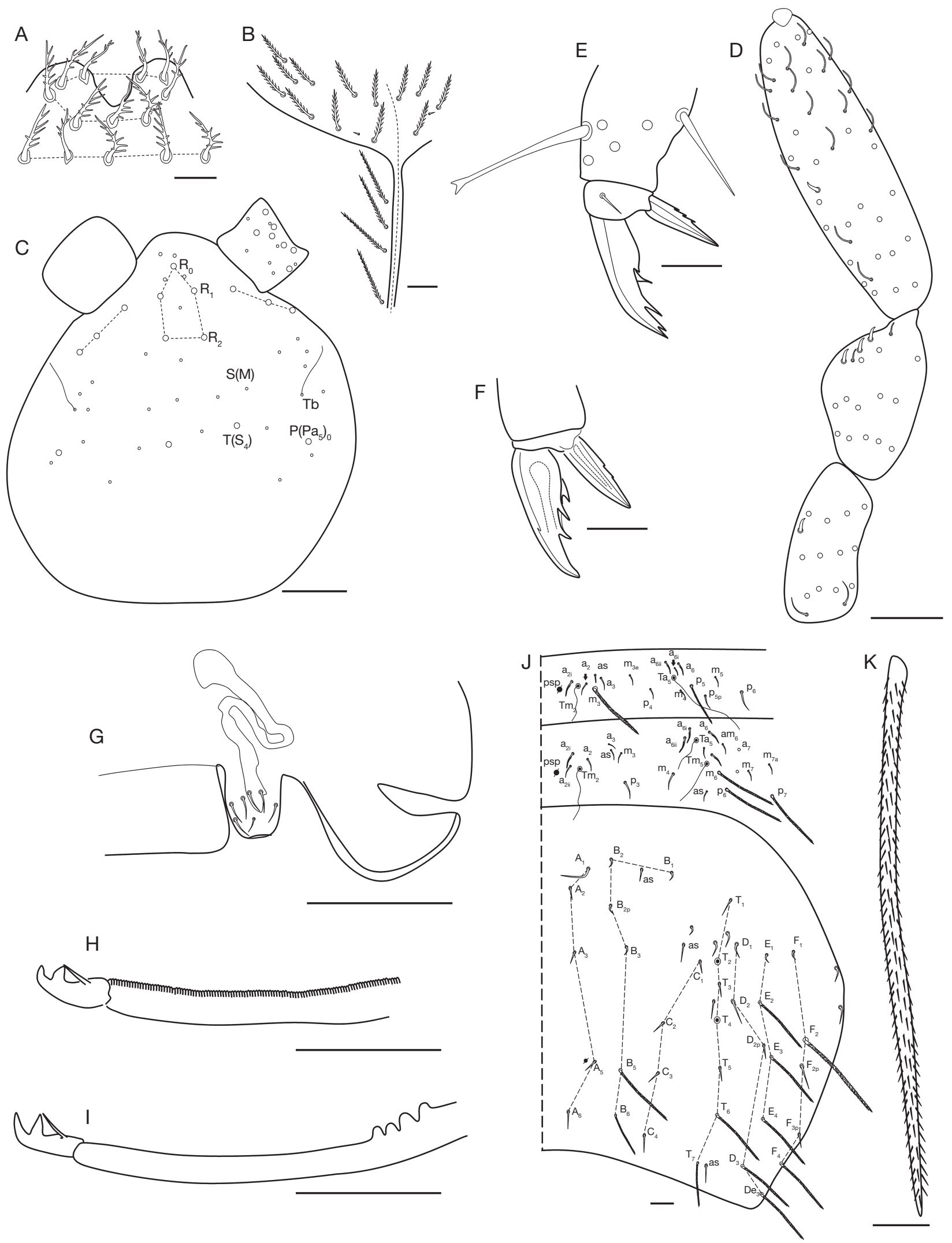

FIG. 5. - A-E, G, I-K, Pseudosinella najtae Jordana \& Baquero, n. sp.: labrum showing the ciliated chaetae (A); labium chaetotaxy (B); head chaetotaxy (the nomenclature follows Gisin \& Da Gama 1969, and in brackets Soto-Adames (2010) (C); Ant. II-IV (D); claw (E); male genital complex (G); dens end and mucro (I); Abd. II-IV chaetotaxy (J); Abd. IV macrochaeta B5 (K); F, H, Pseudosinella infrequens Gisin \& Da Gama, 1969 (drawings from holotype): claw and empodium (F); dens end and mucro (H). Scale bars: A, $4 \mu \mathrm{m} ; \mathrm{B}, 15 \mu \mathrm{m} ; \mathrm{C}, \mathrm{D}, \mathrm{G}, \mathrm{I}, 20 \mu \mathrm{m} ; \mathrm{E}, 10 \mu \mathrm{m}$. 
TABLE 1. - Comparison among species that share the same characters in the claw complex (presence of corner tooth on claw, a tooth on internal lamella of empodium and a terminal filament on empodium surpassing the claw): A, dens, distal ventral or anterior chaeta (ve1): 0, normal; 1, strong spine; B, dens, external spine-like chaetae number; $\mathbf{C}$, dens, E3 as spine-like: 0, normal; 1, spine-like; 2, strong articulated spine; $\mathbf{D}$, dens, internal spine-like chaetae number; E, dens, L1 as spine-like: 0, normal; 1, spine-like; 2, strong articulated spine; F, dens, L2 as spine-like: 0, normal; 1, spine-like; G, dens, L3 as spine-like: 0 , normal; 1, spinelike; $\mathbf{H}$, annal appendix shape: 1 , flat with apex and edges brush-like; 2 , flat and pectinate; I, female anal valves, chaeta $\mathrm{C} 1$ on anal valve shape: 0 , simple; 1 , bifurcate; J, female anal valves, chaeta C2 on anal valve: 0 , normal; 1, swollen at the base; 2 , winged; 3 , dentate at the base; 4, branched; $\mathbf{K}$, female anal valves, chaeta C3 on anal valve: 0 , normal; 1 , swollen at the base; 2 , winged; 3 , dentate at the base; $\mathbf{L}$, female anal valves, chaeta C4 on anal valve: 0 , normal; 1 , swollen at the base; 2, winged; 3, dentate at the base; 4, branched; $\mathbf{M}$, female anal valves, chaeta $\mathrm{C} 5$ on anal valve: 0 , normal; 1 , swollen at the base; 2 , winged; 3 , dentate at the base; 4 , branched; $\mathbf{N}$, female anal valves, chaeta C6 on anal valve: 0 , normal; 1 , swollen at the base; 2 , winged; $\mathbf{0}$, female anal valves, chaeta C8 on anal valve: 0 , normal; 1 , swollen at the base; *, different; Dif, number of differences from the $\mathrm{n}$. sp.

\begin{tabular}{|c|c|c|c|c|c|c|c|c|c|c|c|c|c|c|c|c|}
\hline Species & A & B & C & D & E & $\mathbf{F}$ & $\mathbf{G}$ & $\mathbf{H}$ & I & $\mathbf{J}$ & $\mathbf{K}$ & $\mathbf{L}$ & $\mathbf{M}$ & $\mathbf{N}$ & 0 & Dif \\
\hline Pygmarrhopalites pygmaeus (Wankel, 1860) & 0 & 2 & $2^{*}$ & $3^{*}$ & 1 & $1^{\star}$ & $1^{*}$ & $1^{*}$ & 0 & $1^{*}$ & $1^{*}$ & $1^{*}$ & $1^{*}$ & 1 & 1 & 9 \\
\hline P. plethorasari Zeppelini, Taylor \& Slay, 2009 & - & 2 & $2^{*}$ & $3^{*}$ & 1 & $1^{*}$ & $1^{*}$ & $1^{*}$ & $1^{*}$ & $1^{*}$ & 2 & 4 & $1^{*}$ & 1 & 1 & 8 \\
\hline P. lewisi Christiansen \& Bellinger, 1998 & 0 & 2 & $2^{*}$ & $3^{*}$ & 1 & $?$ & $?$ & $1^{*}$ & 0 & $1^{*}$ & $1^{*}$ & $1^{*}$ & $1^{*}$ & 1 & $0^{*}$ & 8 \\
\hline P. benitus (Folsom, 1896) & 0 & 2 & $2^{*}$ & $3^{*}$ & 1 & $1^{*}$ & $1^{*}$ & $2^{*}$ & 0 & $1^{*}$ & $1^{*}$ & $1^{*}$ & $1^{*}$ & 1 & 1 & 9 \\
\hline P. ater Christiansen \& Bellinger, 1998 & 0 & $1^{*}$ & $0^{*}$ & 1 & 1 & 0 & 0 & $2^{*}$ & 0 & 2 & $3^{*}$ & $3^{*}$ & $3^{*}$ & $2^{*}$ & $0^{*}$ & 8 \\
\hline P. maestrazgoensis Jordana, Fadrique \& Baquero, 2012 & 0 & $1^{*}$ & $0^{*}$ & 0 & 0 & 0 & 0 & $1,5 ?$ & & $1^{*}$ & $0^{*}$ & 2 & 2 & $0(1)$ & $0(1)$ & 4 \\
\hline P. cantavetulae Jordana, Fadrique \& Baquero, 2012 & 0 & 2 & 1 & $3^{*}$ & $2^{*}$ & $1^{*}$ & $1^{*}$ & $1,5 ?$ & & $3^{*}$ & $3^{*}$ & $3^{*}$ & 2 & $2^{*}$ & $0^{*}$ & 9 \\
\hline P. crepidinis Jordana \& Baquero, n. sp. & 0 & 2 & 1 & $0(1)$ & $0(1)$ & 0 & 0 & 5 & 0 & 2 & 2 & 2(4) & 2 & 1 & 1 & - \\
\hline
\end{tabular}

as cilliated microchaetae, there are three am6 microchaetae (two smooth and one ciliated) (Fig. 5J). Accessory chaeta s in the anterior trichobothrial complex of abdominal tergite IV absent (Fig. 5J). P(C1) chaeta on abdominal tergite IV at level of anterior tricobothrium (T2) and as smooth microchaeta. Only B5 and B6 presents as ciliated Mc as Figure 5K. Pseudopore at level of B5. Retinaculum with $4+4$ teeth and one ciliated chaeta.

\section{Legs}

Claw (Fig. 5E) with 4 teeth, basal pair of wing teeth at 50\% of the base of inner edge, and different in size, medial unpaired tooth well developed, approximately $80 \%$ from base. Empodium acuminate with serrate external edge. Tenent hair clavate, longer than claw. Scales only on coxae.

\section{Furca}

Two internal and one external chaetae related to one distal pseudopore of manubrial plate. Mucro with apical tooth long as the apical; basal spine surpassing a little the tip of the anteapical tooth (Fig. 5I). Uncrenulated section of dens four times as long as mucro. Scales on manubrium and dens

\section{DISCUSSION}

In relation to Pygmarrhopalytes crepidinis Jordana \& Baquero, n. sp. twenty species share the following characters: linear bothriotrichal pattern in great abdomen head without spines and with $1+1$ eye and Ant. IV with five segments. Among them Pygmarrhopalites pygmaeus (Wankel, 1860) sensu Stach, 1918; P. benitus (Folsom, 1896) sensu Christiansen, 1966; P. ater Christiansen \& Bellinger, 1998; P. lewisi Christiansen \& Bellinger, 1998; P. plethorasari Zeppelini, Taylor \& Slay, 2009; P. maestrazgoensis Jordana, Fadrique \& Baquero, 2012; P. cantavetulae Jordana, Fadrique \& Baquero, 2012 and P. crepidinis Jordana \& Baquero, n. sp. share the same characters in the claw complex (presence of a tooth on claw, empodium with a corner tooth on internal lamella and a terminal filament surpassing the claw) on all legs (Table 1). Among them only P. maestrazgoensis shares the external spines on the dens with the new species. Table 1 only shows four differences, but the new species is also different by the chaetotaxy of Ant. organ III and Abd. VI (Jordana et al. 2012).

According to the dorsal macrochaetotaxy $(\mathrm{R} 011 / 10 / 0100+2)$ of Pseudosinella najtae Jordana \& Baquero n. sp. and the absence of chaeta $s$ in the anterior trichobothrial complex of the Abd. IV this species is similar only to Pseudosinella infrequens Gisin \& Gama, 1969, described from a cave near Alhama de Murcia (Spain) from two specimens captured on bats' guano. The holotype of $P$. infrequens (MHNG) has been studied: it is different by some characters of the claw, i.e. three teeth (Fig. 5F) against four very patent teeth on the internal edge of the claw of the new species (Gisin \& Da Gama 1969: fig. 2), The empodium is serrated in both species (not illustrated in the original description of $P$. infrequens). Tenent hair a little longer than the claw in the new species and shorter in $P$. infrequens. Mucro of $P$. infrequens with apical tooth smaller than the subapical (Fig. 5H) drawing from the holotype.

The labrum is very special in the new species with formula 4/554 of prelabral/labral chaetae, which are all ciliated (Figs 2E; $5 \mathrm{~A}$ ), and with smooth labral chaetae on holotype. Labium without M1, with M2rEL1L2, r is a smooth microchaetae, all labial chaetae both basal and internal ciliated, something unknown for P. infrequens (because the position the holotype in the slide) in the original description only described as ciliated the basal labial Mc. Both species are from caves of the Southern Spain: Alhama de Murcia vs Sierra de las Estancias, Municipality of Oria, Almería, which are $90 \mathrm{~km}$ apart.

Together with these two new species described above an additional accompanying fauna has been found.

The fauna in the cavity was analyzed based on 4468 specimens collected in the cave during the annual sampling period 
TABle 2. - Fauna of Cueva del Saliente. Abbreviations: Coll, Collembola; Col, Coleoptera; Dip, Diptera; Hym, Hymenoptera; Pso, Psocoptera; Pse, Pseudoscorpionida; Aca, Acari; Ara, Araneae; Iso, Isopoda; Chi, Chilopoda; Gas, Gasteropoda; Lep, Lepidoptera; AUT, Autumn; WIN, Winter; SPR, Spring; SUM, Summer.

\begin{tabular}{|c|c|c|c|c|c|c|c|c|c|c|c|c|c|c|}
\hline & & Coll & Col & Dip & Hym & Pso & Pse & Aca & Ara & Iso & Chi & Gas & Lep & total \\
\hline $\mathrm{T} 1$ & $\begin{array}{l}\text { AUT } \\
\text { WIN } \\
\text { SPR } \\
\text { SUM } \\
\end{array}$ & $\begin{array}{l}0 \\
1 \\
0 \\
1 \\
\end{array}$ & $\begin{array}{l}33 \\
9 \\
4 \\
4 \\
\end{array}$ & $\begin{array}{r}7 \\
0 \\
1 \\
123 \\
\end{array}$ & $\begin{array}{l}0 \\
0 \\
0 \\
0\end{array}$ & $\begin{array}{r}11 \\
2 \\
1 \\
0 \\
\end{array}$ & $\begin{array}{l}0 \\
1 \\
0 \\
0\end{array}$ & $\begin{array}{r}0 \\
132 \\
568 \\
35\end{array}$ & $\begin{array}{l}0 \\
0 \\
0 \\
0\end{array}$ & $\begin{array}{l}0 \\
0 \\
0 \\
0\end{array}$ & $\begin{array}{l}0 \\
0 \\
0 \\
1 \\
\end{array}$ & $\begin{array}{l}0 \\
0 \\
0 \\
0\end{array}$ & $\begin{array}{l}0 \\
0 \\
0 \\
0\end{array}$ & $\begin{array}{r}21 \\
145 \\
574 \\
164 \\
\end{array}$ \\
\hline T2 & $\begin{array}{l}\text { AUT } \\
\text { WIN } \\
\text { SPR } \\
\text { SUM }\end{array}$ & $\begin{array}{l}2 \\
0 \\
1 \\
0 \\
\end{array}$ & $\begin{array}{l}2 \\
1 \\
1 \\
1 \\
\end{array}$ & $\begin{array}{l}4 \\
4 \\
4 \\
6 \\
\end{array}$ & $\begin{array}{l}0 \\
0 \\
0 \\
0\end{array}$ & $\begin{array}{l}0 \\
0 \\
0 \\
0 \\
\end{array}$ & $\begin{array}{l}0 \\
0 \\
0 \\
0 \\
\end{array}$ & $\begin{array}{l}0 \\
0 \\
0 \\
0 \\
\end{array}$ & $\begin{array}{l}0 \\
0 \\
0 \\
0 \\
\end{array}$ & $\begin{array}{l}1 \\
1 \\
0 \\
0 \\
\end{array}$ & $\begin{array}{l}1 \\
0 \\
3 \\
0\end{array}$ & $\begin{array}{l}0 \\
0 \\
0 \\
0\end{array}$ & $\begin{array}{l}0 \\
0 \\
0 \\
0 \\
\end{array}$ & $\begin{array}{r}10 \\
6 \\
9 \\
7 \\
\end{array}$ \\
\hline T3 & $\begin{array}{l}\text { AUT } \\
\text { WIN } \\
\text { SPR } \\
\text { SUM }\end{array}$ & $\begin{array}{l}0 \\
0 \\
0 \\
0 \\
\end{array}$ & $\begin{array}{l}3 \\
3 \\
0 \\
9\end{array}$ & $\begin{array}{r}13 \\
4 \\
0 \\
107 \\
\end{array}$ & $\begin{array}{l}0 \\
0 \\
0 \\
0\end{array}$ & $\begin{array}{l}3 \\
2 \\
1 \\
5 \\
\end{array}$ & $\begin{array}{l}0 \\
0 \\
0 \\
0 \\
\end{array}$ & $\begin{array}{r}49 \\
9 \\
1 \\
195 \\
\end{array}$ & $\begin{array}{l}0 \\
0 \\
0 \\
0 \\
\end{array}$ & $\begin{array}{l}0 \\
0 \\
0 \\
0 \\
\end{array}$ & $\begin{array}{r}10 \\
6 \\
0 \\
0 \\
\end{array}$ & $\begin{array}{l}0 \\
0 \\
0 \\
1 \\
\end{array}$ & $\begin{array}{l}0 \\
0 \\
0 \\
0 \\
\end{array}$ & $\begin{array}{r}78 \\
24 \\
2 \\
317 \\
\end{array}$ \\
\hline T4 & $\begin{array}{l}\text { AUT } \\
\text { WIN } \\
\text { SPR } \\
\text { SUM }\end{array}$ & $\begin{array}{l}0 \\
2 \\
0 \\
0 \\
\end{array}$ & $\begin{array}{r}18 \\
0 \\
5 \\
3 \\
\end{array}$ & $\begin{array}{r}43 \\
8 \\
11 \\
71 \\
\end{array}$ & $\begin{array}{l}0 \\
0 \\
0 \\
0 \\
\end{array}$ & $\begin{array}{r}0 \\
11 \\
3 \\
4 \\
\end{array}$ & $\begin{array}{l}0 \\
0 \\
0 \\
1 \\
\end{array}$ & $\begin{array}{r}2 \\
97 \\
46 \\
50 \\
\end{array}$ & $\begin{array}{l}0 \\
0 \\
0 \\
0 \\
\end{array}$ & $\begin{array}{l}0 \\
0 \\
0 \\
0\end{array}$ & $\begin{array}{l}8 \\
0 \\
0 \\
3 \\
\end{array}$ & $\begin{array}{l}0 \\
0 \\
0 \\
0 \\
\end{array}$ & $\begin{array}{l}1 \\
0 \\
0 \\
0\end{array}$ & $\begin{array}{r}72 \\
118 \\
65 \\
132 \\
\end{array}$ \\
\hline T5 & $\begin{array}{l}\text { AUT } \\
\text { WIN } \\
\text { SPR } \\
\text { SUM }\end{array}$ & $\begin{array}{l}1 \\
0 \\
0 \\
2 \\
\end{array}$ & $\begin{array}{r}0 \\
2 \\
4 \\
14 \\
\end{array}$ & $\begin{array}{l}20 \\
42 \\
10 \\
58 \\
\end{array}$ & $\begin{array}{l}0 \\
0 \\
0 \\
0 \\
\end{array}$ & $\begin{array}{l}0 \\
0 \\
0 \\
0 \\
\end{array}$ & $\begin{array}{l}0 \\
0 \\
0 \\
0 \\
\end{array}$ & $\begin{array}{l}0 \\
1 \\
1 \\
1 \\
\end{array}$ & $\begin{array}{l}0 \\
0 \\
0 \\
0 \\
\end{array}$ & $\begin{array}{l}0 \\
0 \\
0 \\
0\end{array}$ & $\begin{array}{r}2 \\
12 \\
1 \\
6 \\
\end{array}$ & $\begin{array}{l}0 \\
0 \\
0 \\
0 \\
\end{array}$ & $\begin{array}{l}0 \\
0 \\
0 \\
0\end{array}$ & $\begin{array}{l}23 \\
57 \\
16 \\
81 \\
\end{array}$ \\
\hline T6 & $\begin{array}{l}\text { AUT } \\
\text { WIN } \\
\text { SPR } \\
\text { SUM }\end{array}$ & $\begin{array}{r}1 \\
1 \\
18 \\
4 \\
\end{array}$ & $\begin{array}{r}55 \\
0 \\
0 \\
1 \\
\end{array}$ & $\begin{array}{r}94 \\
1 \\
0 \\
28 \\
\end{array}$ & $\begin{array}{l}0 \\
0 \\
0 \\
0 \\
\end{array}$ & $\begin{array}{l}0 \\
0 \\
0 \\
1 \\
\end{array}$ & $\begin{array}{l}0 \\
1 \\
0 \\
0 \\
\end{array}$ & $\begin{array}{l}0 \\
3 \\
0 \\
2 \\
\end{array}$ & $\begin{array}{l}0 \\
0 \\
0 \\
1 \\
\end{array}$ & $\begin{array}{r}10 \\
0 \\
0 \\
0 \\
\end{array}$ & $\begin{array}{r}10 \\
1 \\
2 \\
0 \\
\end{array}$ & $\begin{array}{l}0 \\
0 \\
0 \\
0 \\
\end{array}$ & $\begin{array}{l}0 \\
0 \\
0 \\
0 \\
\end{array}$ & $\begin{array}{r}170 \\
7 \\
20 \\
37 \\
\end{array}$ \\
\hline T7 & $\begin{array}{l}\text { AUT } \\
\text { WIN } \\
\text { SPR } \\
\text { SUM }\end{array}$ & $\begin{array}{l}8 \\
0 \\
8 \\
0 \\
\end{array}$ & $\begin{array}{r}1 \\
3 \\
5 \\
12 \\
\end{array}$ & $\begin{array}{r}54 \\
20 \\
30 \\
160 \\
\end{array}$ & $\begin{array}{l}2 \\
0 \\
0 \\
0 \\
\end{array}$ & $\begin{array}{l}0 \\
0 \\
0 \\
0 \\
\end{array}$ & $\begin{array}{l}0 \\
0 \\
3 \\
0 \\
\end{array}$ & $\begin{array}{l}0 \\
0 \\
1 \\
6 \\
\end{array}$ & $\begin{array}{l}0 \\
0 \\
0 \\
0\end{array}$ & $\begin{array}{l}2 \\
3 \\
2 \\
1 \\
\end{array}$ & $\begin{array}{r}6 \\
13 \\
9 \\
1 \\
\end{array}$ & $\begin{array}{l}0 \\
0 \\
0 \\
0\end{array}$ & $\begin{array}{l}0 \\
0 \\
0 \\
0 \\
\end{array}$ & $\begin{array}{r}73 \\
39 \\
58 \\
180 \\
\end{array}$ \\
\hline T8 & $\begin{array}{l}\text { AUT } \\
\text { WIN } \\
\text { SPR } \\
\text { SUM }\end{array}$ & $\begin{array}{r}0 \\
68 \\
64 \\
1 \\
\end{array}$ & $\begin{array}{r}15 \\
1 \\
4 \\
63 \\
\end{array}$ & $\begin{array}{r}139 \\
26 \\
54 \\
113 \\
\end{array}$ & $\begin{array}{l}1 \\
0 \\
0 \\
0 \\
\end{array}$ & $\begin{array}{l}0 \\
0 \\
0 \\
0 \\
\end{array}$ & $\begin{array}{l}0 \\
0 \\
0 \\
1 \\
\end{array}$ & $\begin{array}{r}0 \\
0 \\
1 \\
10 \\
\end{array}$ & $\begin{array}{l}0 \\
0 \\
0 \\
0 \\
\end{array}$ & $\begin{array}{r}26 \\
0 \\
0 \\
0 \\
\end{array}$ & $\begin{array}{l}5 \\
6 \\
1 \\
9 \\
\end{array}$ & $\begin{array}{l}0 \\
0 \\
0 \\
0 \\
\end{array}$ & $\begin{array}{l}0 \\
0 \\
0 \\
0 \\
\end{array}$ & $\begin{array}{l}186 \\
101 \\
124 \\
197 \\
\end{array}$ \\
\hline T9 & $\begin{array}{l}\text { AUT } \\
\text { WIN } \\
\text { SPR } \\
\text { SUM } \\
\end{array}$ & $\begin{array}{l}0 \\
3 \\
6 \\
2 \\
\end{array}$ & $\begin{array}{r}32 \\
2 \\
4 \\
103 \\
\end{array}$ & $\begin{array}{l}46 \\
34 \\
62 \\
76 \\
\end{array}$ & $\begin{array}{l}0 \\
0 \\
0 \\
1 \\
\end{array}$ & $\begin{array}{l}0 \\
0 \\
0 \\
0 \\
\end{array}$ & $\begin{array}{l}0 \\
0 \\
0 \\
0 \\
\end{array}$ & $\begin{array}{r}8 \\
0 \\
20 \\
26 \\
\end{array}$ & $\begin{array}{l}1 \\
0 \\
0 \\
0 \\
\end{array}$ & $\begin{array}{l}0 \\
0 \\
1 \\
0 \\
\end{array}$ & $\begin{array}{r}44 \\
10 \\
15 \\
2 \\
\end{array}$ & $\begin{array}{l}0 \\
0 \\
0 \\
0 \\
\end{array}$ & $\begin{array}{l}0 \\
0 \\
0 \\
0 \\
\end{array}$ & $\begin{array}{r}131 \\
49 \\
108 \\
210 \\
\end{array}$ \\
\hline $\mathrm{T} 10$ & $\begin{array}{l}\text { AUT } \\
\text { WIN } \\
\text { SPR } \\
\text { SUM }\end{array}$ & $\begin{array}{l}0 \\
0 \\
0 \\
0 \\
\end{array}$ & $\begin{array}{l}8 \\
5 \\
7 \\
0 \\
\end{array}$ & $\begin{array}{r}225 \\
7 \\
11 \\
86 \\
\end{array}$ & $\begin{array}{l}0 \\
0 \\
0 \\
0 \\
\end{array}$ & $\begin{array}{l}0 \\
0 \\
0 \\
0 \\
\end{array}$ & $\begin{array}{l}0 \\
0 \\
0 \\
0 \\
\end{array}$ & $\begin{array}{r}21 \\
6 \\
4 \\
26 \\
\end{array}$ & $\begin{array}{l}0 \\
0 \\
0 \\
0 \\
\end{array}$ & $\begin{array}{l}0 \\
0 \\
0 \\
0 \\
\end{array}$ & $\begin{array}{r}0 \\
28 \\
7 \\
3 \\
\end{array}$ & $\begin{array}{l}0 \\
0 \\
0 \\
0\end{array}$ & $\begin{array}{l}0 \\
0 \\
0 \\
0 \\
\end{array}$ & $\begin{array}{r}254 \\
46 \\
29 \\
115 \\
\end{array}$ \\
\hline $\mathrm{T} 11$ & $\begin{array}{l}\text { AUT } \\
\text { WIN } \\
\text { SPR } \\
\text { SUM }\end{array}$ & $\begin{array}{l}0 \\
0 \\
0 \\
0\end{array}$ & $\begin{array}{l}3 \\
1 \\
0 \\
0\end{array}$ & $\begin{array}{r}9 \\
0 \\
0 \\
60\end{array}$ & $\begin{array}{l}0 \\
0 \\
0 \\
0\end{array}$ & $\begin{array}{l}0 \\
1 \\
0 \\
0\end{array}$ & $\begin{array}{l}0 \\
0 \\
0 \\
0\end{array}$ & $\begin{array}{r}22 \\
119 \\
61 \\
0\end{array}$ & $\begin{array}{l}0 \\
0 \\
0 \\
0\end{array}$ & $\begin{array}{l}0 \\
0 \\
0 \\
0\end{array}$ & $\begin{array}{l}0 \\
1 \\
0 \\
1\end{array}$ & $\begin{array}{l}0 \\
0 \\
0 \\
0\end{array}$ & $\begin{array}{l}0 \\
0 \\
0 \\
0\end{array}$ & $\begin{array}{r}34 \\
122 \\
61 \\
61\end{array}$ \\
\hline $\mathrm{T} 12$ & AUT & 0 & 4 & 7 & 0 & 8 & 0 & 115 & 0 & 0 & 1 & 0 & 0 & 135 \\
\hline Total & $\begin{array}{l}\text { AUT } \\
\text { WIN } \\
\text { SPR } \\
\text { SUM }\end{array}$ & $\begin{array}{r}12 \\
75 \\
97 \\
10 \\
194\end{array}$ & $\begin{array}{r}144 \\
27 \\
34 \\
210 \\
415\end{array}$ & $\begin{array}{r}661 \\
146 \\
183 \\
888 \\
1878\end{array}$ & $\begin{array}{l}3 \\
0 \\
0 \\
1 \\
4\end{array}$ & $\begin{array}{r}22 \\
16 \\
5 \\
10 \\
53\end{array}$ & $\begin{array}{l}0 \\
2 \\
3 \\
2 \\
7\end{array}$ & $\begin{array}{r}217 \\
367 \\
703 \\
351 \\
1638\end{array}$ & $\begin{array}{l}1 \\
0 \\
0 \\
1 \\
2\end{array}$ & $\begin{array}{r}39 \\
4 \\
3 \\
1 \\
47\end{array}$ & $\begin{array}{r}87 \\
77 \\
38 \\
26 \\
228\end{array}$ & $\begin{array}{l}0 \\
0 \\
0 \\
1 \\
1\end{array}$ & $\begin{array}{l}1 \\
0 \\
0 \\
0 \\
1\end{array}$ & $\begin{array}{r}1187 \\
714 \\
1066 \\
1501 \\
4468\end{array}$ \\
\hline
\end{tabular}

(October 2012 to August 2013) (Table 2). All specimens have been classified into 38 taxa with unequal taxonomic accuracy, due the impossibility to identifying all the specimens to the species level. All the material is being progressively determined to species level as taxonomic identifications by specialists in each group progress (Table 2).

The predominant group is the Diptera with $42.03 \%$ (considering adults and larvae). The second largest group in per- centage of specimens is Acari with $36.66 \%$, the remaining taxonomic groups acount for less than $10 \%$ of specimens (Table 2). Collembola represent $4.34 \%$, with three species (two of them new for science).

The three species of springtails captured in this cave, have a different distribution pattern. Troglopedetes absoloni has been captured in the preliminary sampling and only in the pitfall 01 , which was located very near the entrance, in the 
twilight zone. It is probably an opportunistic or accidental species in the cavity, since only three specimens, only in one pitfall have been collected.

The two species described in this work are unevenly distributed in the cavity. Pseudosinella najtae Jordana \& Baquero, n. sp. has been captured from the entrance area to the pitfall number 07 , but not beyond this point, in which a greater number of specimens have been captured. It would be risky to infer habits or ecological requirements of this new species with only 32 specimens, but the area where the pitfall 06 was located is in the upper part of the cavity, where the environment is dry and dusty; environment and the room presents small isolated clusters of bat guano.

Pygmarrhopalites crepidinis Jordana \& Baquero, n. sp. goes more deeply into the cavity, reaching pitfall number 09 . Pitfall 08 gave the largest number of captures. It is located in the Sinforosa room which is very active hydrologically and with abundant accumulation of guano. The Sinforosa and Dolmen rooms house large colonies of bats. Pygmarrhopalites crepidinis Jordana \& Baquero, n. sp. seems to prefer the most active part of the cavity where the atmosphere is more humid (see climate data Sinforosa room). The two species appear to avoid areas of alluvial gravel that are located at certain points of the cavity and correspond to the pitfalls 03,10 and 11 . However, the remaining accompanying fauna is most abundant and diverse in pitfall 01 (near the entrance), 03 (alluvial gravel) and 08 where there is a large accumulation of guano. Although paradoxically pitfall 10 has a maximum population in autumn, it is mainly due to the Sciaridae Diptera and their larvae. Phoridae, Sciaridae, Oribatida and Gamasida are the groups with the highest specimens in the cave. Only the Oribatida (Acari) present a stable population throughout the year with a minimum in spring $(16 \%)$ and its maximum in winter (34\%). Diptera have two major population peaks, in summer with 669 specimens for Phorids and in autumn with 301 specimens of Sciarids. The most extreme case occurs in Gamasida mites, with only one specimen in autumn and 117 captures in spring. In general, the whole fauna has a minimum in winter and a maximum in summer. In the Collembola, for two new species described, the maximum population is in spring. The aridity of summer seems to have a direct impact on the most hygrophilous species, accusing the decline in humidity in the most superficial galleries. The smallest collections, during both phases along Andalusia, were made in the province of Almeria, probably because this province is generally arid and caves are drier than in others provinces. Finally, we must mention the discovery of a new species of pseudoscorpion belonging to the genus Ephippiocthonius Beier, 1930. Only seven specimens of this species were capture throughout the whole year, distributed irregularly along the year and the cave. It was lacking in the autumn sampling, and the maximum number of successive captures were three specimens. The pitfall with the greatest number of specimens is located in the busiest area of the cavity (Sinforosa room): it could be inferred that the species requires high moisture level, which could explain its absence in autumn, after the summer.

\section{Acknowledgements}

This study was cofinanced by European FEADER funds and Consejería de Medio Ambiente y Ordenación del Territorio de la Junta de Andalusia (Spain) via the Project "Propuesta de Servicio para la Conservación de los Invertebrados Amenazados de Andalusia”. We thank to both caving clubs, Espeleo Club Almería (ECA) who made the sampling of the cave, the Asociación Espeleológica Velezana (AEV) and Antonio González Ramón who helped in samplings and provided the topography of the cave. We thank the referees who have corrected this paper and contributed to a substantial improvement. Also thank Peter J. Schwendinger the Natural History Museum of Geneva for allowing observe the type of Pseudosinella infrequens.

\section{REFERENCES}

BarRanco P. 2010. - Descripción de una nueva especie de Petaloptila Pantel, 1890 de Málaga (Orthoptera, Gryllidae). Boletín de la Asociación española de Entomología 31 (1-2): 207-217.

Barranco P., Mayoral J. G. \& ÁlVArez García G. 2014. - Primer registro de esquizómidos en la península ibérica (Arachnida, Schizomida). Boletín de la Asociación española de Entomología 38 (3-4): 295-301.

Belda I. M., Barranco P. \& Mayoral J. G. 2014. - Protección de la fauna invertebrada cavernicola en Andalucía. Cuevatur, Aracena, Huelva: 419-429.

Beier M. 1930. - Die Pseudoskorpione des Wiener Naturhistorischen Museums. III. Annalen des Naturhistorischen Museums in Wien 44: 199-222.

BreTfeld G. 1999. - Synopses on Palaearctic Collembola. Vol. 2. Symphypleona. Abhandlungen und Berichte des Naturkundemuseums Görlitz 17 (1): 1-318.

Christiansen K. \& Bellinger P. 1980. - The Collembola of North America North of the Rio Grande, Part 4, Grinell College, Grinell: 1043-1322.

Christiansen K. \& Bellinger P. 1996. — Cave Arrhopalites: new to science. Journal of Cave and Karst Studies 58: 168-180.

Christiansen K. 1966. - The genus Arrhopalites (Collembola Sminthuridae) in the United States and Canada. International Journal of Speleology 2: 43-73. https://doi.org/10.5038/1827806X.2.1.5

Christiansen K., Bellinger P. \& Da Gama M. M. 1990. — Computer assisted identification of specimens of Pseudosinella (Collembola Entomobryidae). Revue d'Écologie et de Biologie du Sol 27: 231-246.

ENGHOFF H. 2013. - New montane, subterranean congeners of a littoral millipede, genus Thalassisobates (Diplopoda: Julida: Nemasomatidae). Journal of Natural History 47 (23-24): 1613-1625. https://doi.org/10.1080/00222933.2012.759289

FJELLBERG A. 1984. - The maxillary outer lobe, an important systematic tool in Isotomidae (Collembola). Annales de la Société royale zoologique de Belgique 114: 83-88.

Fjellberg A. 1998. - The Collembola of Fennoscandia and Denmark. Part I: Poduromorpha. Brill. Fauna Entomologica Scandinavica 35: 1-183.

Gisin H. \& Da Gama M. M. 1969. - Espèces nouvelles de Pseudosinella cavernicoles (Insecta: Collembola). Revue suisse de Zoologie 76 (6): 143-181. https://doi.org/10.5962/bhl.part.146030

GÓmez M. S., BARRANCO P. \& PÉrEZ-FERNÁNDEZ T. 2013. — What can fleas tell us about animals inhabiting caves? Boletín de la Asociación española de Entomología 37 (1-2): 75-83.

GONZÁlEZ A. 2015. - Las cuevas de los Vélez y su entorno. Un karst diferente. Centro de Estudios Velezanos. Ayuntamiento de Vélez Rubio, 144 p. 
Jordana R., FAdrique F. \& BAQUero E. 2012. — The collembolan fauna of Maestrazgo caves (Teruel, Spain) with description of three new species. Zootaxa 3502: 49-71. https://doi.org/10.5281/ zenodo. 212081

Jordana R., Baquero E. \& ARIÑo A. H. 2016 (continuously updated). - Collembola DELTA database: Pseudosinella taxonomy. University of Navarra. Accessed on 2016.V.29 at http:// www.unav.es/unzyec/collembola/Pseudosinella/

Molero R., Bach C., Sendra A., Montagud S., Barranco P. \& GAJU M. 2013. - Revision of the genus Coletinia (Zygentoma: Nicoletiidae) in the Iberian Peninsula, with description of nine new species. Zootaxa 3615 (1): 1-60. https://doi.org/10.11646/ zootaxa.3615.1.1

Ortuño V. \& Barranco P. 2013. - Duvalius (Duvalius) lencinai Mateu \& Ortuño, 2006 (Coleoptera: Carabidae: Trechini) una especie hipogea del sur de la Península Ibérica. Morfología, reubicación taxonómica, sistemática y biología. Animal Biodiversity and Conservation 36 (2): 141-152.

Ortuño V. \& BarRanco P. 2015. - Un nuevo Trechus (Coleoptera, Carabidae, Trechini) hipogeo de la Sierra de Parapanda (Andalucía, España): taxonomía, sistemática y biología. Animal Biodiversity and Conservation 38 (2): 191-206.
Ribera C. \& De MÁs E. 2015. - Description of three new troglobiontic species of Cybaeodes (Araneae, Liocranidae) endemic to the Iberian Peninsula. Zootaxa 3957 (3): 313-323. https://doi. org/10.11646/zootaxa.3957.3.4

Soto-Adames F. N. 2010. - Two new species and descriptive notes for five Pseudosinella species (Hexapoda: Collembola: Entomobryidae) from West Virginian (USA) caves. Zootaxa 2331: 1-34. Soto-Adames F. N., Jordana R. \& BAQuero E. 2014. — Comparative analysis of the dorsal Chaetotaxy of Troglopedetes, Trogolaphysa, and Campylothorax supports the synonymization of tribes Paronellini and Troglopedetini (Collembola: Paronellidae). Journal of Insect Science 14 (278): 1-16. https://doi.org/10.1093/jisesa/ieu140

SZEPTYCKI A. 1979. - Chaetotaxy of the Entomobryidae and its phylogenetical significance. Morpho-Systematic studies on Collembola. IV. Polska Akademia Nauk, Warszawa, 218 p.

Tinaut A., Barranco P. \& Fernández D. 2015. - Nuevas localidades para Aphaenogaster cardenai Espadaler, 1981 (Hymenoptera, Formicidae). Boletín de la Asociación española de Entomología 39 (3-4): 421-424.

VARGOVITSH R. S. 2009. - New Cave Arrhopalitidae (Collembola: Symphypleona) from the Crimea (Ukraine). Zootaxa 2047: 1-47. https://doi.org/10.5281/zenodo.186465 
